\title{
Cement slurries for sealing high temperature and high reservoir pressure boreholes
}

\begin{abstract}
A number of cement slurries proposed for sealing casing string in boreholes, where dynamic temperatures are in the range range from about 110 to about $150^{\circ} \mathrm{C}$ and pressures from 45 to $90 \mathrm{MPa}$, were investigated and analyzed in this article. In developing recipes were guided by the requirements to be met by cement slurry for the cementing of casing in the conditions of the occurrence of very high temperatures and reservoir pressures. Before the application of cement slurry in industrial conditions, the density, viscosity, thickening time, cement setting, free water and compressive strength of cement stone were examined. Developed cement slurries for HPHT conditions in research carried out in the Oil and Gas Institute - National Research Institute, had densities in the range from 1865 to $1890 \mathrm{~kg} / \mathrm{m}^{3}$ and after appropriate fluidifying were characterized by good rheological parameters. Thickening times of the developed cement slurries ranged from approx. 4 to approx. $6 \frac{1}{2}$ hours, and can be successfully adjusted (most effectively with a suitably selected additive of sodium lignosulfonate in an amount of about $0,25 \div 1 \%$ ). The initial viscosities of the cement slurries tested in the HPHT consistometer were small (about $10 \mathrm{Bc}$ ). The course of changes in the consistency of cement slurries was "rectangular", and time between the consistency of 30 and $100 \mathrm{Bc}$ was generally short (about 10 minutes or less). Cement stones formed after bonding of developed cement slurries were characterized by extremely high mechanical parameters. After 2 days, compressive strength of most tested samples exceeded $25 \mathrm{MPa}$, and after 7 days of hydration, the compressive strength was about $35 \mathrm{MPa}$. The cement slurry recipes presented in the article can be used for sealing casing strings in our country or in Ukraine (where cementation is performed in deep boreholes).
\end{abstract}

Key words: cement slurry, cement stone, high temperature, high pressure, cementing.

\section{Zaczyny cementowe do uszczelniania otworów wiertniczych o wysokich temperaturach i ciśnieniach złożowych}

W artykule przedstawiono opis i analizę badań szeregu zaczynów cementowych proponowanych do uszczelniania kolumn rur okładzinowych w otworach wiertniczych, w których występują temperatury dynamiczne w zakresie od około $110^{\circ} \mathrm{C}$ do około $150^{\circ} \mathrm{C}$ i ciśnienia od $45 \mathrm{MPa}$ do $90 \mathrm{MPa}$. Przy opracowywaniu receptur kierowano się wymaganiami, jakie powinien spełniać zaczyn cementowy użyty do cementowania rur okładzinowych w warunkach występowania bardzo wysokich temperatur oraz ciśnień złożowych. Przed zastosowaniem zaczynu cementowego w warunkach przemysłowych zwracano uwagę na jego gęstość, lepkość, czas gęstnienia, wiązanie, filtrację, odstój wody oraz wytrzymałość kamienia cementowego na ściskanie. Opracowane w INiG - PIB zaczyny cementowe do warunków HPHT posiadały gęstości od $1865 \mathrm{~kg} / \mathrm{m}^{3} \mathrm{do} 1890 \mathrm{~kg} / \mathrm{m}^{3}$ i po odpowiednim upłynnieniu cechowały się dobrymi parametrami reologicznymi. Czasy gęstnienia zaczynów cementowych wynosiły od około 4 godzin do około 6,5 godziny i można je z powodzeniem regulować (najskuteczniej za pomocą odpowiednio dobranego dodatku lignosulfonianu sodowego w ilości około $0,25 \div 1 \%$ ). Lepkości początkowe zaczynów badanych w konsystometrze ciśnieniowym były niewielkie (wynosiły około 10 Bc). Przebieg zmian konsystencji zaczynów cementowych miał charakter ,prostokątny”, a czas pomiędzy uzyskaniem konsystencji 30 Bc i 100 Bc był z reguły krótki (około 10 minut lub krócej). Kamienie cementowe powstałe po związaniu opracowanych zaczynów cechowały się niezwykle wysokimi parametrami mechanicznymi. Już po 2 dniach wytrzymałość na ściskanie większości badanych próbek przekraczała $25 \mathrm{MPa}$, natomiast po 7 dniach hydratacji wynosiła około $35 \mathrm{MPa}$. Zaprezentowane w artykule receptury zaczynów mogą być zastosowane podczas uszczelniania kolumn rur okładzinowych w naszym kraju lub na obszarze Ukrainy (gdzie mamy do czynienia z wykonywaniem prac cementacyjnych w głębokich otworach wiertniczych).

Słowa kluczowe: zaczyn cementowy, kamień cementowy, wysoka temperatura, wysokie ciśnienie, cementowanie. 


\section{Introduction}

In the recent years, petroleum companies in our country have been increasingly commencing the drilling of deep boreholes, whose final depths reach approx. 4000 meters (e.g. G-2, L-11H, $\mathrm{M}-4 \mathrm{~K}, \mathrm{M}-5 \mathrm{KH}, \mathrm{R}-5 \mathrm{H}, \mathrm{K}-2 \mathrm{H}$, etc.). Dynamic temperatures present at the bottoms of these holes reach $110 \div 125^{\circ} \mathrm{C}$, with pressures of $70 \div 80 \mathrm{MPa}$. Our eastern neighbors in Ukraine regularly drill boreholes to great depths reaching 5000 $\div 5500$ meters (temperatures at the bottoms of these boreholes reach $140 \div 150^{\circ} \mathrm{C}$ ). With such a considerable depth of a borehole (where the temperature and pressure are very high), it is a serious problem to provide a long pumping time of cement slurry, which should be characterized by low viscosity, minor water settling and the lowest possible filtration. Therefore, one should select proper retardant and dispersing agents which are resistant to the impact of high temperatures, as well as other additives guaranteeing proper technological parameters of the slurry and the cement stone.

The paper uses the analyses of a number of cement slurries suggested for sealing casing strings in a dynamic tempera- ture from approx. 110 to approx. $150^{\circ} \mathrm{C}$. The preparation of recipes abided by the requirements which are to be fulfilled by a cement slurry used to cement the casing string under the conditions of the presence of very high temperatures and formation pressures. Before the application of a cement slurry under industrial conditions, its primary examinations involved the density, viscosity, thickening time, cement setting, free water and compressive strength of the cement stone. This is because it is a known fact that apart from factors affecting the efficiency of sealing casing strings in boreholes, such as the proper preparation of a borehole, the technology of performing the procedure, primary significance is attributed to the cement slurry which should exhibit specific properties. The composition and parameters of the slurry depend mainly on the geological and hydrogeological conditions of the borehole in which the process of setting and formation of cement stone occurs, the type of penetrated rocks, the depth, temperature and pressure at the bottom of the borehole $[15,16]$.

\section{Main physical conditions in deep boreholes affecting the selection of the recipe of a cement slurry}

Deep boreholes are characterized by particular physical conditions which are to be absolutely considered when designing the procedure of cementing the casing string. For instance, the dynamic temperature which is a result of the active transfer of heat by liquids circulating in the borehole has a decisive function when selecting the recipe of the slurry. The flow of the drilling fluid, the buffer and the cement slurry lowers the temperature at the bottom of the borehole and changes the distribution of temperatures over its whole length. Due to this, the gradients of static and dynamic temperature usually differ considerably from each other; hence the analytical determination of the dynamic temperature, especially in boreholes with considerable depths, is relatively inaccurate. Aside from the depth, the value of the dynamic temperature is very heavily affected by the rate of flow (the circulation of liquid), the diameter of the borehole, the properties of flowing liquids and the specific heat of rocks. The relatively low thermal conductivity of sedimentary rocks and high thermal resistance created by the filter cake make it so that differences in the values of the static and dynamic temperature at the bottom of the borehole as well as the drilling fluid temperature at the outflow may reach several dozen degrees $[1,2,12]$.

The highest dynamic temperature during the circulation of liquid in the borehole is present not in the near-bottom zone, but at a height of approx. $3 / 4$ of the borehole depth, and it exceeds the downhole temperature by several (sometimes even about a dozen) degrees Celsius. The location of the highest temperature point $T_{\max }$ depends on the individual conditions present in the given borehole (e.g. flow rate, temperature gradient and borehole depth). The position of point $T_{\max }$ moves up in the hole in the annular space along with an increase in flow rate.

The literature [7] describes the so-called Edwardson's model, enabling the determination of the value and depth of the highest established temperature of the flowing drilling fluid (slurry) in the annular space. When using this model to predict the approximate profile of the temperature of liquid flowing in the annular space of the borehole, it has been assumed that the temperature gradient of the rock mass changes in a straight line, while the results produced with this assumption are accurate enough for the engineering objectives.

The increase in downhole temperature to a specified height from the bottom of the hole is advantageous for the setting of the cement slurry upon pumping it into the annular space of the borehole. This guarantees that the cement slurry is set within the specified time not only in the near-bottom zone of the borehole, i.e. under the conditions of the temperature for which its composition has been adjusted, but also over a longer segment of the annular space, due to the abovementioned distribution of temperatures.

The most credible results in terms of determining the distribution of the dynamic temperature in the borehole are produced by a direct measurement at the bottom of the borehole (e.g., by the use of proper geophysical probes). 


\section{Additives to cement slurries intended for use in boreholes with high temperatures and formation pressures}

In the case of sealing very deep boreholes $(3500 \div 4500$ meters), the high temperature and pressure present at the bottom of the hole cause the necessity to use a number of modifying agents for sealing slurries $[5,6,8,9]$. They include the following additives:

- defoaming (reducing the amount of air present in the slurry),

- dispersing, i.e. lowering the viscosity of the slurry, (adjusting the rheological - structural parameters),

- lowering filtration and water settling (protecting against the loss of water from the slurry),

- extending the duration of initial thickening (delaying the setting process).

The most important of the above-mentioned additives are the so-called setting retarders. The mechanism of action of the retarders has not yet been entirely explored and explained in the world literature. They probably modify the growth rate of crystals and their morphology as a result of their adsorption on a layer of hydrated cement, due to which they slow down the growing process of calcium hydroxide crystallization nuclei. Over time, the additives of retarders are removed from the solution due to being embedded into the structures of the hydrated material, which however does not cause the creation of different hydrates.

Four theories explaining the mechanism of action of the retarders have been proposed in the world literature:

- the theory of adsorption - the delay is associated with the adsorption of the retarder on the surfaces of the products of hydration, thus hindering the contact with water,

- the theory of precipitation - the retarder reacts with calcium already in the aqueous phase, generating an insoluble and impermeable layer around cement grains,

- the theory of crystallization - the retarder is adsorbed on the crystals of hydration products and delays or destroys their further growth,

- the theory of bonding - calcium ions undergo gelation by the retarder, preventing the creation of crystals.

\section{Types of retarding agents $[3,4]$}

One can distinguish several classes of retarders, different both in terms of their use and their mechanism of action. These are:

- Lingosulfonates,

- Hydrocarboxylic Acids,

- Cellulose Derivatives,

- Organic Phosphates,

- Inorganic Components.

Lignosulfonates are the most frequently used agents in cement slurries (at the same time most efficiently delaying the setting process). They are calcium and sodium salts of lignosulfonic acids. Lignosulfonic compounds are created as a by-product during cellulose manufacturing. They are very efficient towards nearly all groups of cements, and their added amounts range from $0.1 \%$ to $1.5 \%$ bwoc (i.e. in relation to dry cement mass).

The retarding action of lignosulfonates is explained by the theory of adsorption and crystallization [10-14]. By being adsorbed on the surface of C-S-H gel they undergo morphological changes into a more permeable layer. Its waterproof action prevents further hydration. Some of the lignosulfonates in the aqueous phase remain in their free state or are bound with calcium ions by electrostatic forces. It has been proven that with their low concentration, the crystallization of calcium hydroxide is halted; hence, a similar result is to be expected in the case of C-S-H gel. Changes in the morphology and dimensions of $\mathrm{Ca}(\mathrm{OH})_{2}$ crystals in the presence of lignosulfonates were also observed during the experiments. The performed research indicates that if the generation and growth of grains as the products of hydration is halted by the action of the retarding additives, it will look similar in the case of the $\mathrm{C}_{3} \mathrm{~A}$ hydration process, especially with a low $\mathrm{C}_{3} \mathrm{~A}$ content of cement.

\section{Laboratory tests}

Laboratory tests intended to develop compositions of cement slurries with adjustable rheological parameters for high formation temperatures were performed in the Drilling Technology Department of the OaGI - NRI according to the following standards: PN-EN 10426-1 and 10426-2 Oil and gas industry-Cements and borehole cementing materials - part 1 and 2: Drilling cement testing, PN-85/G-02320 Cements and cement slurries for cementing in boreholes and API SPEC 10 Specification for materials and testing for well cements [17, 18].

Cement slurries intended for high formation temperatures were prepared on the basis of drilling cement G HSR, also add- ing silica fume (microsilica) in order to improve the thermal resistance of the hardened cement slurry. Recipes for dynamic temperatures amounting to 110,130 and $150^{\circ} \mathrm{C}$ were prepared with pressures from 45 to $90 \mathrm{MPa}$, inputting a simulated time of pumping (reaching the temperature and pressure) from 60 to 165 minutes. This was done with the use of chemical agents used by the Cementing Service of Exalo. Therefore, proper defoaming, dispersing, anti-filtration and setting retardant additives were used. During the studies, a number of setting retarders were tested in order to choose an agent which acts the most efficiently in very high temperatures. Out of the produced results, the paper 
presents four recipes (marked with the symbols A, B, C and D) which exhibited optimal technological parameters (Tables 1, 2).

When conducting the test in a temperature of $110^{\circ} \mathrm{C}$, two slurries with the most advantageous technological parameters were chosen. Slurry A used $0.25 \%$ of the retarding additive and other additives listed in Table 1. The slurry prepared in such a manner had very good technological parameters. Its density amounted to $1865 \mathrm{~kg} / \mathrm{m}^{3}$, water settling was zero, filtration amounted to $82 \mathrm{~cm}^{3} / 30 \mathrm{~min}$ and the consistencies of $30 \mathrm{Bc}$ and $100 \mathrm{Bc}$ were reached after $4 \mathrm{~h} 37 \mathrm{~min}$ and $5 \mathrm{~h} 06 \mathrm{~min}$, respectively (Figure 1). After 7 days of hydration, the cement stone

Table 1. The compositions of cement slurries tested under HPHT conditions

\begin{tabular}{|l|c|c|c|c|}
\hline \multirow{2}{*}{ Components of the recipe } & Slurry A & Slurry B & Slurry C & Slurry D \\
\cline { 2 - 5 } & $110^{\circ} \mathrm{C} / 60 \mathrm{MPa}$ & $110{ }^{\circ} \mathrm{C} / 45 \mathrm{MPa}$ & $130^{\circ} \mathrm{C} / 80 \mathrm{MPa}$ & $150{ }^{\circ} \mathrm{C} / 90 \mathrm{MPa}$ \\
\hline Water-cement ratio (w/c) & 0.53 & 0.50 & 0.53 & 0.53 \\
\hline Defoamer & $0.3 \%$ bwoc & 0.5 bwoc & $0.3 \%$ bwoc & $0.3 \%$ bwoc \\
\hline Dispersant (plasticizer) I & $0.3 \%$ bwoc & - & $0.3 \%$ bwoc & $0.3 \%$ bwoc \\
\hline Dispersant (plasticizer) II & - & $0.3 \%$ bwoc & - & - \\
\hline Anti-filtration additive I & $0.2 \%$ bwoc & - & $0.2 \%$ bwoc & $0.2 \%$ bwoc \\
\hline Anti-filtration additive II & - & $0.6 \%$ bwoc & - & - \\
\hline Powdered latex & - & $1.2 \%$ bwoc & - & - \\
\hline Setting retarder I & $0.25 \%$ bwoc & - & $0.6 \%$ bwoc & $1.0 \%$ bwoc \\
\hline Setting retarder II & - & $0.35 \%$ bwoc & - & - \\
\hline NaCl (sodium chloride) & - & $10 \%$ bwow & - & - \\
\hline Microsilica (silica fume) & $20 \%$ bwoc & $10 \%$ bwoc & $20 \%$ bwoc & $20 \%$ bwoc \\
\hline Drilling cement G & $100 \%$ & $100 \%$ & $100 \%$ & $100 \%$ \\
\hline
\end{tabular}

bwoc - by weight of cement

bwow - by weight of batched water reached compressive strength of approx. $37 \mathrm{MPa}$ and adhesion to casing of approx. $4 \mathrm{MPa}$. Recipe B contained in its composition properly selected polymers, setting retarder II, a dispersant, a defoamer and powdered latex. The slurry was batched with a $10 \% \mathrm{NaCl}$ saline and it had a density of $1890 \mathrm{~kg} / \mathrm{m}^{3}$, zero water settling, and its filtration amounted to $52 \mathrm{~cm}^{3} / 30 \mathrm{~min}$. The slurry reached a consistency of $30 \mathrm{Bc}$ after $6 \mathrm{~h} 14 \mathrm{~min}$ and $100 \mathrm{Bc}$ after $6 \mathrm{~h} 26 \mathrm{~min}$. After 7 days, the cement stone reached compressive strength of approx. $33 \mathrm{MPa}$ and its adhesion to the casing amounted to $4 \mathrm{MPa}$. Slurry $\mathrm{C}$ with a density of $1870 \mathrm{~kg} / \mathrm{m}^{3}$ (test performed in a temperature of $130^{\circ} \mathrm{C}$ and pressure of $80 \mathrm{MPa}$ ) contained the amount of retarder I increased to $0.6 \%$. Its technological parameters were very good. Water settlement was zero, filtration amounted to $80 \mathrm{~cm}^{3} / 30$ min and the consistencies of $30 \mathrm{Bc}$ and $100 \mathrm{Bc}$ were reached after 5 h $53 \mathrm{~min}$ and $6 \mathrm{~h} 02 \mathrm{~min}$, respectively. The hardened cement slurry had compressive strength amounting to approx. $35 \mathrm{MPa}$ after 7 days of hydration. Its adhesion to steel pipes then amounted to approx. $5 \mathrm{MPa}$. In slurry D with a density of $1870 \mathrm{~kg} / \mathrm{m}^{3}$ (tested in a temperature of $150^{\circ} \mathrm{C}$ and pressure of $90 \mathrm{MPa}$ ), the amount of the setting retarder was increased to $1 \%$, by

Table 2. The parameters of cement slurries and cement stones tested under HPHT conditions

\begin{tabular}{|c|c|c|c|c|}
\hline & Slurry A & Slurry B & Slurry C & Slurry D \\
\hline $\begin{array}{l}\text { The tested parameter of fresh } \\
\text { or hardened cement slurry }\end{array}$ & $\begin{array}{c}110^{\circ} \mathrm{C} / 60 \mathrm{MPa} \\
\text { Time of reaching: } \\
100 \mathrm{~min}\end{array}$ & $\begin{array}{c}110^{\circ} \mathrm{C} / 45 \mathrm{MPa} \\
\text { Time of reaching: } \\
60 \mathrm{~min}\end{array}$ & $\begin{array}{c}130^{\circ} \mathrm{C} / 80 \mathrm{MPa} \\
\text { Time of reaching: } \\
120 \mathrm{~min}\end{array}$ & $\begin{array}{c}150^{\circ} \mathrm{C} / 90 \mathrm{MPa} \\
\text { Time of reaching: } \\
165 \mathrm{~min}\end{array}$ \\
\hline Slurry density $\left[\mathrm{kg} / \mathrm{m}^{3}\right]$ & 1865 & 1890 & 1870 & 1870 \\
\hline Water settling $[\%]$ & 0.0 & 0.0 & 0.0 & 0.0 \\
\hline Plastic viscosity $[\mathrm{mPa} \cdot \mathrm{s}]$ & 121.5 & 212.0 & 144.0 & 102.0 \\
\hline Yield point $[\mathrm{Pa}]$ & 6.0 & 3.5 & 9.1 & 2.9 \\
\hline Setting time $30 \mathrm{Bc}$ [h:minutes] & $4: 37$ & $06: 14$ & $05: 53$ & $04: 29$ \\
\hline Setting time $100 \mathrm{Bc}$ [h:minutes] & 05:06 & $06: 26$ & 06:02 & $04: 32$ \\
\hline Slurry filtration $\left[\mathrm{cm}^{3} / 30 \mathrm{~min}\right]$ & 82 & 52 & 80 & 72 \\
\hline The compressive strength of stone after 2 days [MPa] & 30.3 & 26.2 & 32.7 & $\mathrm{ND}^{*}$ \\
\hline The compressive strength of stone after 7 days [MPa] & 36.7 & 32.9 & 35.2 & $\mathrm{ND}^{*}$ \\
\hline Adhesion to steel pipes after 2 days [MPa] & 4.0 & 3.8 & 4.2 & $\mathrm{ND}^{*}$ \\
\hline Adhesion to steel pipes after 7 days [MPa] & 4.2 & 4.0 & 4.7 & $\mathrm{ND}^{*}$ \\
\hline
\end{tabular}

${ }^{*} \mathrm{ND}$ - not determined 
doing so producing a recipe with very good technological parameters. Water settlement from the slurry was zero, filtration amounted to $72 \mathrm{~cm}^{3} / 30 \mathrm{~min}$ and the consistencies of $30 \mathrm{Bc}$ and

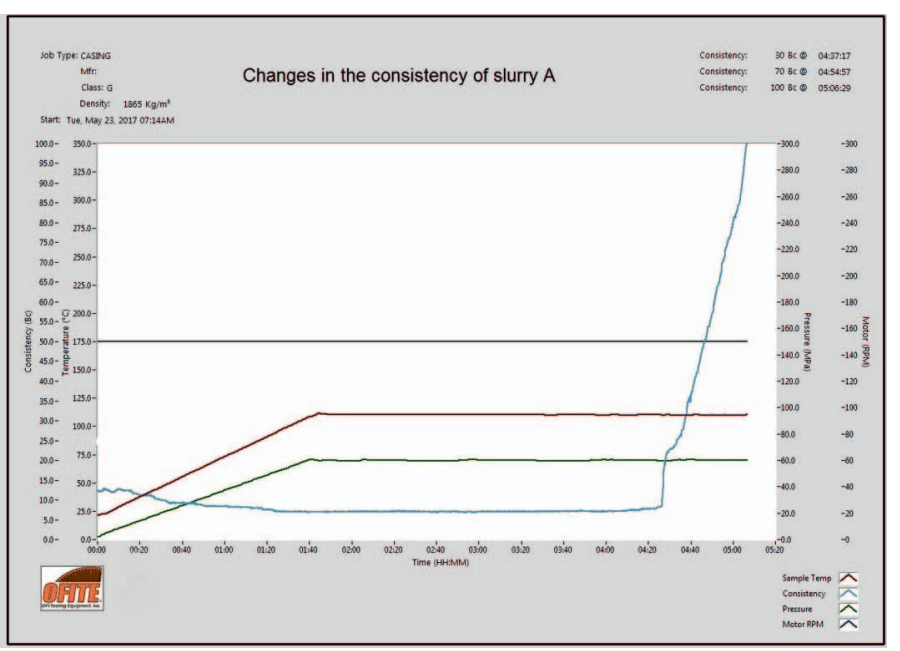

Fig. 1. Changes in the consistency of slurry A in a temperature of $110^{\circ} \mathrm{C}$

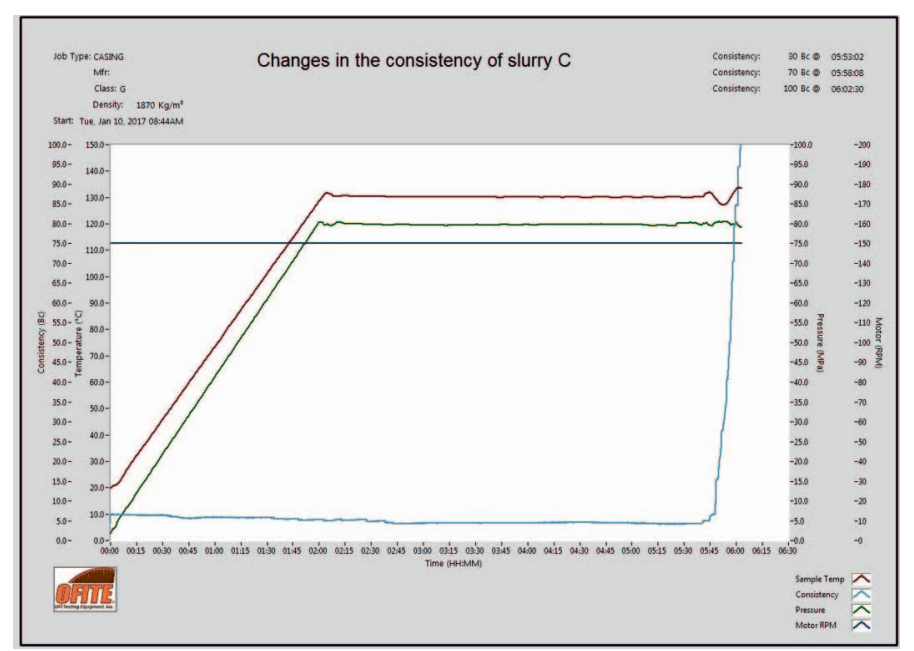

Fig. 3. Changes in the consistency of slurry $\mathrm{C}$ in a temperature of $130^{\circ} \mathrm{C}$
$100 \mathrm{Bc}$ were reached after $4 \mathrm{~h} 29 \mathrm{~min}$ and $4 \mathrm{~h} 32 \mathrm{~min}$, respectively. The resulting recipe $\mathrm{D}$ may be successfully used to seal boreholes with depths exceeding 4500 meters.

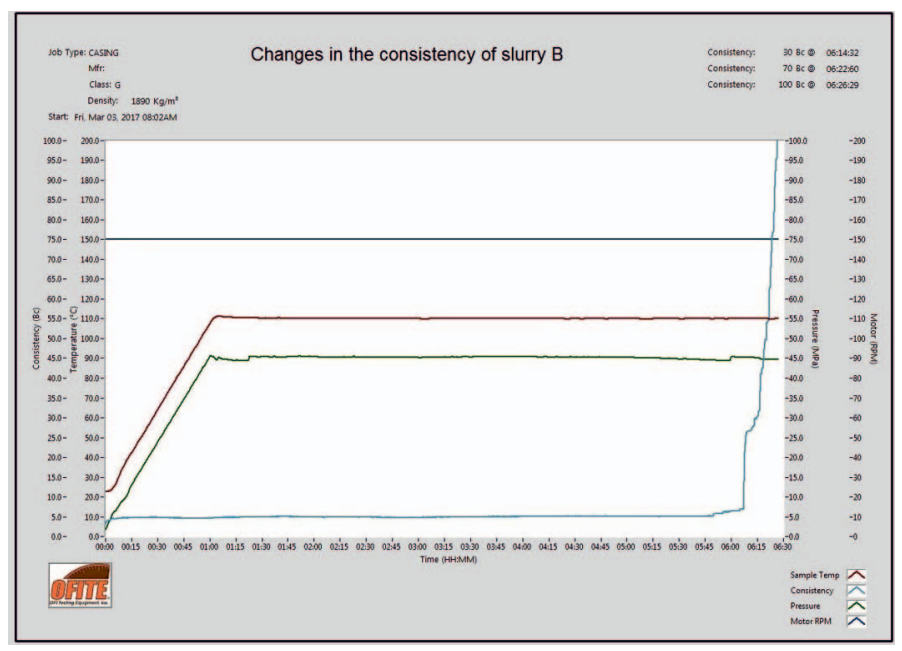

Fig. 2. Changes in the consistency of slurry B in a temperature of $110^{\circ} \mathrm{C}$

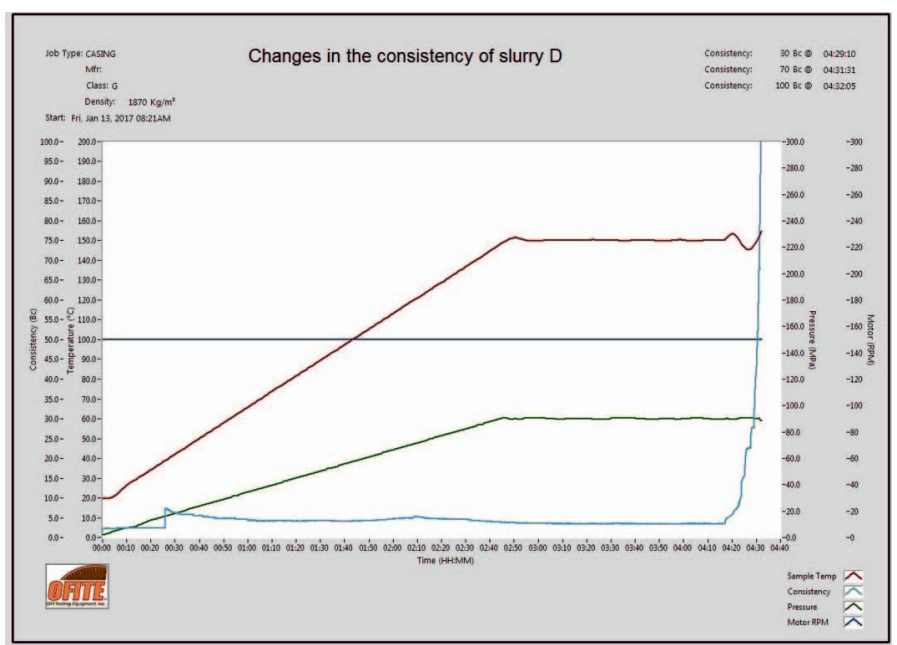

Fig. 4. Changes in the consistency of slurry $\mathrm{C}$ in a temperature of $150^{\circ} \mathrm{C}$

\section{Summary}

After the performance of a number of tests and analyses of liquid and hardened cement slurries, it can be concluded that:

1. Laboratory tests resulted in the preparation of the recipes of sealing slurries for a dynamic temperature of approx. $110 \div 150^{\circ} \mathrm{C}$ and a pressure of approx. $60 \div 90 \mathrm{MPa}$. These slurries were batched with fresh or saline water.

2. The densities of cement slurries varied between 1865 and $1890 \mathrm{~kg} / \mathrm{m}^{3}$. They can be intended for use when sealing casing strings in our country or in Ukraine (where work is performed in deep boreholes).

3. The technological parameters of the developed cement slurries could be easily adjusted by additives commonly used in domestic drilling industry.
4. Upon coupling them with proper dispersing agents, the cement slurries were characterized by good rheological parameters.

5. Thickening times of the developed cement slurries ranged from approx. 4 to approx. $6 \frac{1}{2}$ hours, and they can be successfully adjusted (most effectively with a suitably selected additive of sodium lignosulfonate in an amount of about $0.25 \div 1 \%$ ).

6. The initial viscosities of slurries tested in the HPHT consistometer were small (about $10 \mathrm{Bc}$ ). The course of changes in the consistency of cement slurries was "rectangular", and the time between a consistency of 30 and $100 \mathrm{Bc}$ was generally short (about 10 minutes or less). 
7. Filtrations of the studied slurries with the addition of an antifiltration agent amounted to approximately $50 \div 80 \mathrm{~cm}^{3} / 30 \mathrm{~min}$.

8. The developed cement slurries had zero water settling.

9. Cement stones formed after the bonding of developed cement slurries were characterized by extremely high mechanical parameters. Already after 2 days, the compressive strength of most tested cement stone samples exceeded $25 \mathrm{MPa}$, and after 7 days of hydration, the compressive strength was about
$35 \mathrm{MPa}$. The adhesion of the cement stone to steel pipes was also very high (after 2 days it amounted to approx. $4 \mathrm{MPa}$ and after 7 days it increased to approx. $4 \div 5 \mathrm{MPa}$ ).

10. The developed recipes of slurries can be found useful in the process of cementing casing strings under the conditions of high temperatures and formation pressures, where there is an increasing frequency of dealing with the drilling of boreholes reaching depths of $4000 \div 5000$ meters.

Please cite as: Nafta-Gaz 2018, no. 10, pp. 739-744, DOI: 10.18668/NG.2018.10.05

Article contributed to the Ediotr 24.11.2017. Approved for publication 18.10.2018.

This paper was written on the basis of the statutory work entitled: Cement slurries with adjustable rheological parameters for high formation temperatures - the work of the Oil and Gas Institute - National Research Institute was commissioned by the Ministry of Science and Higher Education; order number: 0061/KW/17/01, archival number: DK-4100-48/2017.

\section{Literature}

[1] Anjos M.A.S., Martinelli A.E., Melo D.M.A., Renovato T., Souza P.D.P., Freitas J.C.: Hydration of oil well cement containing sugarcane biomass waste as a function of curing temperature and pressure. Journal of Petroleum Science and Engineering 2013, vol. 109, s. 291-297 (www.elsevier.com/locate/petrol).

[2] Bensted J.: Retardation of Cement Slurries to $250^{\circ} \mathrm{F}$. Offshore Europe, Aberdeen, UK, 3-6.09.1991, SPE 23073.

[3] Boul P.J., Ellis M., Thaemlitz C.J.: Retarder Interactions in Oil Well Cements AADE-16-FTCE-12. Aramco Research Center, Houston, AADE-2016.

[4] Dębińska E.: Ocena działania dodatków opóźniających czas wiazania zaczynów cementowych na podstawie badań laboratoryjnych. Nafta-Gaz 2012, no. 4, pp. 225-232.

[5] Gonet A., Stryczek S., Pinka J.: Analysis of Rheological Models of Selected Cement Slurries. Acta Montanistica Slovaca Ročník 2004, no. 9, číslo 1, pp. 16-20.

[6] Gonet A., Stryczek S.: Reologia wybranych zaczynów uszczelniających wykonanych z cementów Górażdże Cement S.A. Sympozjum Naukowo-Techniczne „Cementy w budownictwie, robotach wiertniczych i inżynieryjnych oraz hydrotechnice", Piła-Płotki 2001.

[7] Habrat S., Raczkowski J., Zawada S.: Technika i technologia cementowań w wiertnictwie. Wydawnictwo Geologiczne, Warszawa 1980.

[8] Herman Z., Migdał M.: Problemy cementowania rur oktadzinowych na Niżu Polskim. Nafta-Gaz 1998, no. 12, pp. 542-553.

[9] Nalepa J.: Problemy związane z cementowaniem głębokich otworów wiertniczych. Sympozjum Naukowo-Techniczne „Cementy w budownictwie, robotach wiertniczych i inżynieryjnych oraz hydrotechnice", Piła-Płotki 2001.

[10] Rzepka M., Kremieniewski M., Dębińska E.: Zaczyny cementowe przeznaczone do uszczelniania eksploatacyjnych kolumn rur oktadzinowych na Niżu Polskim. Nafta-Gaz 2012, no. 8, pp. 512-522.

[11] Rzepka M., Kremieniewski M.: Zaczyny cementowe do uszczelniania głębokich otworów wiertniczych. Oil and Gas Engineering, Poltava National Technical University, Poltava 2017, vol. 2, pp. 43-56, ISSN 2518-1955.

[12] Rzepka M., Stryczek S.: Laboratoryjne metody określania parametrów technologicznych świeżych zaczynów uszczelniających przed zabiegiem zwiazanym z procesem uszczelniania kolumn rur okładzinowych w otworach wiertniczych. Wiertnictwo, Nafta, Gaz 2008, vol. 25, j. 2, pp. 625-636.

[13] Salim P., Amani M.: Special considerations in cementing high pressure high temperature wells. International Journal of Engineering and Applied Sciences 2013, vol. 1, no. 4, pp. 120-146.
[14] Souza P.P., Soares R.A., Anjos M.A., Freitas J.O., Martinelli A.E., Melo D.F.: Cement slurries of oil wells under high temperature and pressure: the effects of the use of ceramic waste and silica flour. Brazilian Journal of Petroleum and Gas 2012, vol. 6, no. 3, pp. 104-113.

[15] Stryczek S., Gonet A.: Wymagania odnośnie zaczynów uszczelniajacych stosowanych $w$ technologiach wiertniczych. Sympozjum Naukowo-Techniczne „Cementy w budownictwie, robotach wiertniczych i inżynieryjnych oraz hydrotechnice”, Piła-Płotki 2001.

[16] Stryczek S., Małolepszy J., Gonet A., Wiśniowski R., Kotwica Ł., Złotkowski A., Ziaja J.: Popioty z fluidalnego spalania węgla brunatnego jako dodatek do zaczynów uszczelniajacych. Wydawnictwa Naukowe Akademii Górniczo-Hutniczej, Kraków 2013.

\section{Legal and normative acts}

[17] PN-EN ISO 10426-1 Przemyst naftowy i gazowniczy - Cementy i materiały do cementowania otworów - część 1: Specyfikacja.

[18] PN-EN ISO 10426-2 Przemyst naftowy i gazowniczy - Cementy i materiaty do cementowania otworów - czesść 2: Badania cementów wiertniczych.

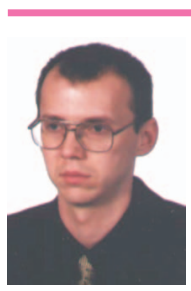

Eng. Marcin RZEPKA Ph.D.

Head of the Sealant Laboratory at the Drilling

Technology Department

Oil and Gas Institute - National Research Institute

ul. Lubicz 25 A

31-503 Kraków

E-mail: marcin.rzepka@inig.pl

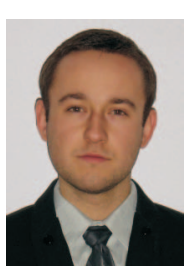

Eng. Marcin KREMIENIEWSKI Ph.D.

Assistant Professor at the Drilling Technology

Department

Oil and Gas Institute - National Research Institute

ul. Lubicz 25 A

31-503 Kraków

E-mail:marcin.kremieniewski@inig.pl

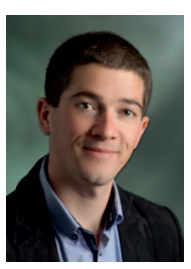

Miłosz KĘDZIERSKI M.Sc.

Engineering and Technical specialist at the Drilling Technology Department

Oil and Gas Institute - National Research Institute

ul. Lubicz 25 A

31-503 Kraków

E-mail: milosz.kedzierski@inig.pl 